\title{
THE GROWTH OF THE CHURCH IN THE MISSION FIELD
}

\section{THE LIVINGSTONIA MISSION}

\section{EARLY HISTORY}

The Livingstonia Mission of the United Free Church of Scotland was founded in $\mathbf{1 8 7 5}$ in memory of David Livingstone. It was the pioneer of civilization and the evangel in Nyasaland. The sphere of the Mission is an area of about 50,000 square miles in north-west Nyasaland and north-east Rhodesia, having a population of about 400,000 people. When the Mission entered those inland regions the whole tribal system was restless and in the constant turmoil of war. Most of the tribes are related to the Nyanja or Tumbuka groups, and at that time had no strong civil organization, or powerful chief. The Arab slavers had established themselves at two or three points on the Lake shore, and were then in great prosperity. On the plateau to the west of the Lake the dominant tribe was the Ngoni, a people of Zulu origin who had recently come into those regions. Their armies raided the weaker tribes annually, and reduced them to a condition of terror, wiping out whole clans, devastating vast tracts of country, sending people who clung to liberty and their own land into fastnesses of thicket and marsh where they stockaded themselves against their enemies. For years there was no civil power behind the Mission to control the people, and the Mission sought to introduce the era of peace by quietly and unostentatiously teaching their industries, opening little schools where they were permitted, healing the sick, and preaching the Gospel. 
To-day a notable victory has been won, and the civil turmoil has given place to settled peace. Vast numbers of natives are able to read, and the whole land is covered with a network of schools. A Church rapidly increasing in numbers and intelligence is becoming a strong factor in the land, and the people are beginning to recognize, in some feeble fashion perhaps, that the law of Christ is the ultimate appeal in all matters of ethics and government.

\section{PREPARATION FOR EVANGELIZATION}

The rapid growth of the Church within the sphere of the Livingstciaia Mission is to be accounted for partly by the altered conditions which have made evangelization possible and have prepared the people to respond to the message. While the whole land was restless from continual war, a calm declaration and reception of the Gospel was impossible. Itineration was not allowed among the Ngoni, and among the subject tribes it was attended with considerable danger and disturbance. When peace gradually crept over the land it came partly through the fact that the territory of the disturbing tribe, the Ngoni, had been occupied by the Mission, and that the new commandments wer beginning to percolate into the minds of the people, especially of the young men who constituted the most dangerous element. Also we must acknowledge the settling influence of the British Government. Few of the regions in which the Livingstonia Mission was working were administered by the British, or had resident magistrates, until after the tribes had abandoned their marauding habits, and had made a general response to the call of industry, education, and the evangel. But the news that a strong power was administering the surrounding tribes gave a feeling of confidence to the weaker people, and exercised a great restraint on the plundering propensities of the warriors. Schools were springing up in all directions, and each of them was as good as an armed fort for keeping 
the peace in the neighbourhood. Great numbers of the men were learning to work, and were proving that the rewards of industry are greater than those of war. And thus more favourable conditions were created for the reception of the Gospel.

There is no doubt that the greatest pioneer agency for Christianity has been the schools. I do not think that one ever finds an isolated declaration of our spiritual message break with startling suddenness in a native's mind, and lead him into the obedience of Christ. A vast deal of reiteration, and simple teaching of each theme and each demand of the Gospel are necessary before men understand how great Christ's claims are, and where the way of salvation lies. This is the main use of the schools to the Mission. Their daily Bible lesson and daily worship gradually awakened the people to the message of the Gospel, and it was chiefly from within the schools that the first converts were obtained. There are now 735 village schools with 47,000 pupils on the rolls.

\section{'THE EARIY CHRISTIANS}

The earliest Christians made their profession at some cost to themselves. They necessarily withdrew themselves from the circles of magical influence and superstitious custom which controlled the social life of the village; and they were therefore reckoned disloyal to their community. It required considerable decision of character to be a Christian, for each new disciple had to live in self-imposed isolation. Surrounded all day by viliage life which bore as constant a relation to him as family life does to people in Great Britain, he lived apart from it, for he could not join in the convivial circle that surrounded the beer-pot, nor take part in the village dances that made the moonlight nights merry, nor summon the witch-doctor in cases of sickness. IHis puritanism became a nuisance to his fellowvillagers. 
But when the leaven began to spread, and large numbers came to profess Christianity, new social groups were formed, and a public conscience began to suppress much of the village life that was objectionable. Then the difficulties of Christian profession were largely removed, and the guarantees of a sincere attitude to Christ were not so secure. Yet in spite of the larger opportunities for teaching the few who professed, and for estimating their character in those earlier days, I doubt whether the average spiritual perception and Christian intelligence of those who were received into the Church were as high as they are today when vast numbers are annually baptized. The fuller education which villagers now receive, and the higher standard of native preachers, seem to have considerably increased the knowledge of what Christianity means to those who adopt it.

\section{THE EXTENSION OF THE CHURCH}

From the first the members of the Church have been taught that they were 'saved to serve.' Opportunities for work, by teaching in the Sunday school, reading the Gospel in villages and huts, preaching in simple fashion in the village street, have been given to all intelligent Christians. The Church from its infancy has been a working body, with considerable ambitions for extension. The vast number of those who to-day profess Christ have not been won through the European's preaching so much as by the efforts, immature enough in all truth, of the native Christians. It must be acknowledged that little control has been exercised over the ordinary village preachers, and that the message they give is sometimes very uninstructive, and even harsh. Denunciation of sin seems to be much easier than exposition of positive truths, and possibly the reputation of public preaching has suffered somewhat from the inefficiency of the preacher. The one thing that Church members and heathen alike demand is, 
that the conduct of those who take it upon them to expound shall be consistent with their profession. And when lads have fallen into sin, it is seldom that they have ever ventured to preach, even when the $\sin$ was not a matter of public knowledge.

Tribal dimensions and a village community are so much within the range of each native's loyalty and interest that possibly this sense of responsibility for others is not hard to develop. Fach village, which is as a single household in its interests, has numbers of heathen, and the Christian members of the community cannot be content until their faith prevails. Within each tribe there are heathen villages, whose inhabitants are related in some fashion to those of other villages, so that all are known to each other. And the native Christians ane made to feel that they cannot be content until their whole people are won for Christ. In addition to this internal home mission work each one of the older stations has adopted a foreign mission or extension area in some more distant tribe. It was in the days when the native Church was still small and surrounded by a dominant heathenism that this extension work was begun. Native teachers were sent forth by the Church to one of the tribes lying in the western hinterland. Their salaries were partly met by the contributions of the Christians who sent them, and no increase of pay was given to them in spite of the fact that they were working far from home and enduring some hardship. This foreign enterprise has had a most healthy effect on the churches that undertook it. It has greatly stimulated liberality, widened the horizon of the Christians, increased their sense of responsibility for the extension of the kingdom of God, and it has given an opportunity for sacrifice on the part of native teachers which has been a constant blessing to them. But in addition to the blessing which has come to the givers, a great work of evangalization has been done among the distant peoples to whom the native missionaries have been sent. 
Now the result of all this effort on the part of native Christians has been of increasing value. The articulate declaration of the Christian laws of conduct has created a new conscience among the people. One may object to the crude preaching of ignorant lads as affording little spiritual nourishment. But their constant denunciation of evils against which public opinion did not formerly protest has compelled the ordinary villager to recognize new sins. When the denunciation has been backed by the written and, to the native mind, absolutely authoritative Word of God, no one attempts to gainsay it. We all recognize that the preacher himself has not yet appreciated the breadth and height of the mind of Christ, and that he makes a disproportionate emphasis on certain public sins, scarcely aware of the grace and importance of other aspects of the New Testament law, and that perhaps he does not speak enough of the attraction of the positive virtues of a Christian disposition. But his limited range has revolutionized many aspects of village life. Drunkenness, polygamy, the craft of the witch-doctor, raiding, licentious dancing, dirt and indolence, neglect of the old, abandoning of abnormal children, worship of the tribal gods and ancestral spirits-these and other common customs which were indulged in openly and without rebuke are to-day known to be wrung, and men acknowledge that they are not following the ideal life when they practise them, though they may not be Christians.

The preachers are all able also to emphasize truths which, under the influence of the Spirit of God, have led men and women into faith. The story of the Incarnation and the death of the Son of God for the sins of the world can at least be told when it cannot be explained. The promise of everlasting life, the awful judgment to come, when the wicked who reject God's offer will be punished and the believer will enter into bliss, have often awakened the hearers, and helped to pierce the night that overshadows death. The message of a present, loving, and omnipotent 16 
God has been a wonderful thing to men who found them. selves surrounded by great powers they could not control, and who never ventured to think of the Creator as con. cerned with present-day matters. Prayer as a direct and potent dealing with a hearing God has linked simple souls to the Father.

These are the subjects which the ordinary village preacher ventures to handle in his own rambling and incoherent way, and the effect of it all is seen in the conscience that has been awakened, and in the increasin? number of souls who are gathered into the Church.

The tendency of the ordinary African to follow his leader and to move in groups accounts for a great number who profess Christianity. Fven in the most disintegrated tribe, where there are no chiefs of importance, there are headmen who exercise a traditional authority, and command the loyalty of their people. In the few cases where these leaders have embraced Christianity they have been followed by large numbers of their people. But somehow few of the old men, and very few of the native chiefs, have become Christians. The demands on them are greater than on the common people. Drunkenness is a regal condition ; beer is the ordinary food of an aristocrat. Polygamy is considered to be a necessary proof of authority, and when the lold headman or the chief would become a disciple of Christ he has to face social degradation, and a possible loss of authority, because he renounces certain of its customary marks. Some young lads who were apparently ardent Christians before they succeeded their fathers in the chieftainship, were subjected to so great temptation that they fell back into polygamy and drunkenness, and by their fall drew many others with them. Here is the weakest point in the whole Christian movement among the Nyasa people. It has deeply affected the younger generation, and has gathered crowds of women, old and young, but it has failed to conquer the stereotyped headman, or to hold the young chiefs permanently to the Christian rule of conduct. 
The total Christian community is now over 30,000 . During the past few years about 1800 adults have been baptized annually, and about 1500 others received into the catechumenate. As there are only eight Furopean stations in the Mission, this large number of admissions has meant a great responsibility for those who receive them, and has necessitated a very careful scrutiny. The way that leads to full communion is long, and the tests are fairly severe.

\section{ENTRANCE TO THE CHURCH}

The initial class of preparation for those who desire to be acknowledged as Christians is called the 'Hearer's Class.' Into this all inquirers enter, and they go through a course of instruction in the main outlines of the Gospel, and in the Commandments and Lord's Prayer, which lasts through two school terms. When this course is ended, should the inquirer desire to proceed further, he is examined personally by his native elder, and if he passes his tests he is sent on for a personal interview with his European missionary, or native pastor. After satisfactorily answering their questions, his name is sent down to the local church members who pronounce on his general conduct, and if they agree to receive him as a catechumen he is solemnly adnitted before the whole congregation.

He now enters an eighteen months', or two years' course of fuller instruction, which ranges over the salient points of Old Testament history and the gospels, and includes a doctrinal and ethical catechism. When this course is completed he may present himself as a candidate for baptism. The native elder is his first examiner. Then, as before, the successful candidates are passed on to the European, who inquires into his personal religion, and knowledge of the main doctrines of our faith. The names of those who come through this catechism with intelligence are again submitted to the native Christians, and afterwards to the elders in session. Should any be found to 
have marriage complications, or village quarrels, or to be living unworthily, they are then dropped. But the approved ones are publicly received into the Church by baptism, and afterwards are admitted to the Lord's Table.

This somewhat elaborate process secures for us a fairly intelligent Church whose members have shown a worthy and consistent profession. Verbal declaration of having renounced the works of darkness has to be proved by continuous conduct. Waverers are tested by the long courses of instruction, and these ensure that all who receive the sacraments have had due opportunity of understanding their meaning, and what is involved in following Christ. We insist, also, on all young applicants being able to read the Word of God, so that the growth of the Church may continue.

It is unfortunate that after baptism we have no guarantee of further progression in Christian intelligence. The greatest opportunity for instructing the Christians is during their catechumenate. Afterwards it is a very voluntary matter whether the church member moves on any further with systematic education. Yet it must be admitted that from the time of baptism onwards lies the most important period. The human elements that have been gathered within the Church require to be led into greater likeness to Christ, stimulated towards liberality and Christian service, and a Church has to be organized which will undertake the spiritual responsibilities for its own people, censuring what is evil, encouraging what is good, and learning to control its own activities without European help. How we attempt to gain those aims may be seen from what follows.

\section{CHURCH ORGANIZATION}

A few years after the various congregations came into being, and as soon as they had attained to the numbers of a few score of members, and had among them men of proved character and intelligence, they were asked to 
elect native elders. As the membership and the number of conspicuous and responsible Christians has increased, more and more elders have been added by the election of the Christians in full communion. These elders meet monthly in session under the presidency of the ordained missionary, and discuss matters of the government and discipline of the Church. They are given a large responsibility for the organization of the public worship in the schools and churches within their districts. They do pastoral work, visiting the sick, conducting funerals, helping in domestic difficulties, and seeking the erring. Their knowledge of the Christians within their area is most intimate, and without their help it would be impossible for the European to control the discipline of the native Church, or to estimate aright the character of those who apply for baptism. Their service is given without any kind of pay, and the office is coveted, perhaps because of the authority which accompanies it. But the Church is still so young, and character is so untested, that it has been found right to have the elders elected only for a period of three or five years, at the end of which period they demit office, and a fresh election takes place, usually, though not always, of the same elders.

In addition to these officers, churches which have had time to develop elect a band of deacons, younger men whose special work it is to look after the finance of the church, and to care for the poor. Their work is not a popular one, as it involves stimulating the members and catechumens to greater liberality. But it has the compensation of disbursing little sums of money to the widows and invalids of the church, a work which is immensely popular. To a people who have only recently begun to use money as a currency, the control of church finance is no simple affair. They are apt to be over liberal about its distribution, and to find its collection an onerous task. But year by year there is a growing intelligence in this work, and some time soon we should be able to find a number of trained leaders 
who know how to accept responsibility for a year's budget, and make income and expenditure agree.

The deacons meet periodically under the presidency of the ordained missionary, and discuss the matters that come within their province. They serve for a period of two or three years, and are not always very eager to accept office for a further period when they are re-elected, for they find their duties unpopular, and making considerable demands on their time without any remuneration. In recent years a serious difficulty has arisen owing to the lack of local labour. Thousands of young men migrate annually to the Rhodesian mines, and to other industrial centres, and are absent for a year or many years at a time. As most of the deacons are vigorous young men, we are constantly confronter with the difficulty of having to let them go for long absences, which involves the laying down of their office.

Enormous congregations have been growing round single stations; the area for which one European station is responsible may extend to over 10,000 square miles, in which there are as many as 150 out-schools. Fach of these out-schools soon becomes a centre of Christianity with the nucleus of a congregation. It follows that the supervision and management of this widely scattered people is much too large to be undertaken by any native pastor. At each of two of the European stations there are already more than 2500 members.

With a view to preparing the Church for native pastorates, these great districts are being broken into parishes, or sub-districts, of a size that might be manageable for a native minister. In some cases the organization of the parish is as follows.

A parish may consist of about a dozen schools, working a dozen groups of little villages. The schools are taught by native teachers, and superintended by a trained schoolmaster. The elders and deacons of the parish are made a local committee of the main session and deacons' court, 
and they meet monthly under the presidency of an evangelist. At their meetings they discuss in detail all matters of their parish which come within their responsibility, and keep a record of their discussions and decisions in their minute books. But they have no final powers, of jurisdiction. Before they can make any decision affecting church members, their business is submitted to the main meetings of the session, and is finally adjudicated there. In this way these little groups of elders and deacons are being trained in church government, and in accepting the responsibilities which must finally come to them when they are under native ordained clergymen.

The evangelist who presides over these parishes is a senior and tested man, chosen from among the elders, and he does the work of an assistant minister. He has been a teacher for some years, has proved his powers as an evangelist, and is undergoing, or has undergone a course of three short terms at Livingstonia, where we have a central training institution for teachers, preachers, and artisans. Here he has special instruction in Christian doctrine, exegesis, and other theological subjects. From among the evangelists, the students who are being trained for the ministry are chiefly chosen; those who have shown that they have spiritual power and insight, and that they have the gift of controlling and organizing the work of others, are again sent to the Institution for a further training in theology. Of this class none have yet completed their education, but it is hoped that in a year or two a goodly number will be ready to be put in charge of native parishes as ordained ministers. Their long years of practical work, and their proved worth and character, should guarantee a ministry to whom the Church may give ordination with confidence and hope. With their evangelist's and subsequent pastor's course they will have had at least six terms of special education at the Institution. All through their practical training they are in touch with their European missionary, reporting to him month by 
month on their work, and receiving his constant guidance.

One of the chief dangers of giving crdination to a people recently rescued from barbarism is that while educational attainments may be easily ascertained, there is no good test of established Christian character. To push a bright lad through a long literary course at an institution where he lives in an atmosphere which is necessarily foreign to that found in village life, and then ordain him, may give to the Church educated pastors who have little influence on village life, and whose characters have still to be testud. It is therefore found to be safer and better to choose for ordination senior men who have already given years of proved service, and who have been able to secure the confidence of their fellow Christians. Their seniority possibly makes them less capable of mental development, but they are more completely in touch with the atmosphere of their tribesmen, and their work gains for them an influence to which younger men cannot attain.

As regards the larger organization of the Church it only remains to say, that all the congregations are united under a Presbytery, which meets once a year, and is attended by the Furopean ministers and elders, and by representative elders from all the native congregations. To this Presbytery all larger matters of discipline, which involve a new precedent, are referred, and thus a code of laws for the Church is gradually being built up, as necessity leads. There is only a very simple constitution with a few clauses on government and Christian doctrine. This constitution has been drawn up in conjunction with the Presbytery of the Blantyre mission of the Church of Scotland, with whom we hope to come into corporate union in a few months, and form a synod as the uniting church court.

We still look towards a larger union: and meanwhile a federation of most of the churches in Nyasaland has been fornied, which unites in observing common rules of discipline, and a general missionary comity. Whether this 
is paving the way for a general organized union of the Christian churches in Nyasaland remains to be seen.

\section{THE GIFTS OF THE CHURCH}

For many years back persistent efforts have been made to encourage the liberality of the people. Fees are now charged for education, and although the fee may be only a small one of twopence, or its value in produce, a lesson is thus given on self-help. School books are also bought by the pupils, and the school houses erected by their own labours and without cost to the European Church. It was only possible to initiate these things after the people had come to see the value of education. The fact that what they are getting costs them something seems to have led them to prize their education and their buildings much more highly than if they had been the free gift of the wealthier European Church.

From the beginning monthly Sunday collections have been taken at the services for public worship. These have generally led to weekly collections. Then as church life develops, a system of monthly house-to-house collecting is started. This is controlled by the deacons. They have possibly each a band of men and women as collectors who go each month through the homes of all the church members and catechumens and receive their gifts. No stated sum has been prescribed. Each gives as his heart dictates. Sometimes the gift is exceedingly small, especially when it is contributed in the form of food stuffs. But it must be remembered that most of the members are exceedingly poor, and many have no money at all. It is not the richest who give most liberally, but the poor widows who seldom seem to have more than is necessary for their bare wants. The food stuffs are gathered together by the deacon, and turned into cash by selling them to any who are willing to buy, and all the collections dealt with at the deacon's meetings are the final results in cash. 
The income thus received is spent on various matters. Part goes to pay the evangelists' salaries, which come to eight or fourteen shillings a month. Part is distributed among lonely widows, and helpless invalids, and there is no more popular object of charity than this. Part is given to help the foreign mission enterprise of the native Church, and part to meet current expenses of the Church. We try to make all the spiritual service of the congregations lean entirely upon the support of the Christians themselves, without the aid of European money. Most of the education expenses are met with foreign grants, and the teachers are our chief preachers. But preaching is not demanded from them as part of their paid duty.

The evangelists, however, and native pastors, of which latter class there are as yet only two or three, give their entire time to the service of the Church, and their salaries are wholly met by the offerings of the people. The problem of the scale on which the future pastors may be paid is a serious one. In two or three years an increasing number of these will be ready for work, and the native Church must support them. With the full education they have

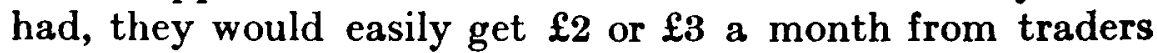
or in government service, and at the mining centres they would get several times this sum. But the finances of the native Church will not be able to bear much more than $f 1$ at the most. The ordinary labourer in Nyasaland gets about 4s. a month, and the skilled artizan, builder or

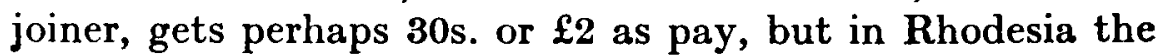
labourer may get $\mathfrak{2} 2$ a month, and most of the vigorous youths go south to work for the larger pay. Every year the temptations to more expensive living are increasing. And it is hard for the educated servants of the Church to find themselves salaried according to local standards, when all their compeers go to the more remunerative depôts in the south, and return with gold in their belts. Yet the average Central African gets so small a wage when he does work locally, and the majority of the villagers live in so 
great poverty, that it seems as if evangelists and ministers who are paid by the local church should be paid in relation to the local standard of wealth. What salary the Christians may finally judge to be a fair one, and what the ministers may believe to be an adequate one, remains to be seen. Unfortunately the standard of salary is a serious matter for those whom it touches. And as the only regular employees in the country, whether in industrial or educational work, have been paid by Europeans, and therefore have had an experience of drawing from what they reckoned to be unfluctuating wealth, the future ministers look forward with some misgiving to dependence on the liberality of the native Church, and to having their salaries determined by their fellows.

\section{DISCIPLINE}

In maintaining the discipline of the Church the native eldership is invaluable. When the missionary is assisted by a band of high-toned elders, jealous for the reputation of the Church, the most minute control is possible. For it is seldom that a villager can be guilty of a breach of the moral law, even in the most secret way, without its coming to light eventually. The supposed magical consequences of transgression of social rectitude are so numerous that some time or other they seem to bring the sinner within range of their threats, and lead him to confession, or to be charged by those with whom he has secretly sinned. The most common causes of backsliding are fornication and adultery, and these usually lead to polygamy. Then the apostate, feeling that he has burned his boats, plunges into drunkenness, and other un-Christian acts. When once a man has lapsed into polygamy it is very seldom that he ever returns to a Christian profession.

Lapsing back to drunkenness is not so frequent as a first sin. I do not think that men suffer severely from alcoholic cravings. But one can understand how severe the 
isolation of a Christian may be when he is the only one in a heathen village who follows the temperance and virtue of Christ. In the evenings all the social life of the people centres round the beer-pot. There the stories and laughter and dance will be found, while the Christian sits by himself with little to do. Thus, apparently, it is the craving for friendship and social bonds that give the greatest pull on the man who has voluntarily cut himself off from others.

A large number of questions arise out of marriage relations, which men are not always ready to answer according to the rule of the Church. Thus the old-established custom of inheritance of widows, the marriage with a deceased husband's brother, divorce through mutual incompatibility, or because of the taint of leprosy, or incurable disease, or because of the indolence, or criminal tendencies or malignant hatred of the wife-these habits of the past make it hard to obey the Christian rule of marriage, and it is not always easy to make the Christian recognize how self-interest must be suppressed and a cross must be carried so that Christ may triumph here also.

It must be admitted that as a general rule even church discipline does not tend to edification. It certainly purifies the body of the Church by removing unworthy members, but it seems to have little reformatory value upon the sinner. At present the most serious question before the Church is how to deal with backsliders that they may not be driven by despair to compromise their future hopelessly by plunging into paganism, but may rather feel that the faithful Christians have left every possible door open for their return.

Considering that the supervision of the Church is so strict and minute, I fancy that the percentage of failures annually compares favourably with that of the home Church. Somewhere about 3 per cent. of the members are suspended each year. Yet this number is great, and every case is a wound for the earnest missionary, who has come to love each member as one of the household of God. 


\section{METHODS OF INSTRUCTING THE CHURCH}

To bring men to a confession of Christ is a great work. But to lead the Christians into a larger knowledge of Christ and truer likeness to Him is a greater still. With a people widely scattered, few of whom can attend the European's preaching at his central station, and most of whom are dependent upon what very untrained teachers can give them, some methods have to be devised which will lead them into progressive knowledge. These vary in the separate stations, but perhaps the most useful thing I can do is to sketch the methods in use in my own station.

First, arrangements are made for the instruction of the teachers and preachers. The evangelists who superintend the religious teaching of their parishes have themselves had the advantage of a special training at the Institution, and every month they come to their missionary to discuss their work, and receive some guidance in their methods and reading. They are continually on tour among their people, holding little conventions when they recognize special needs, supplementing the instruction given by the teachers to the catechumens, and stimulating the elders and teachers. The teachers and evangelists also spend an entire month every year at the European station, receiving instruction which aims not purely at educational results, but seeks also to make them better preachers of the Word. On the first week of each month, or of every second month, a sacramental season is held at the central station, to which Christians gather from the far outlying villages. This season, lasting for two or three days, gives a unique opportunity for teaching the Church. Five or six services are held, and one truth is taught throughout until the preacher feels that it has gripped his audience, and he has sent them back charged with teaching which ought to make them stronger and better.

In addition to this, throughout the year extensive tours are made over the whole district. Besides visiting the 
various schools, the missionary holds at each centre a three days' convention for the local Christians and catechumens, when again he gives a series of sermons on some great Christian truth.

But we must chiefly rely on the Christians being a reading people. So far the New Testament only has been translated into the dialects of Nyasaland. But the Ngoni people who have retained, to some degree, their knowledge of Zulu have had the great advantage of receiving the whole Bible in a tongue which they can understand. Some care is taken that the younger generation of Christians shall be able to read, and none are admitted to church fellowship until they have attained to this. But one cannot say that there are many who have reached the stage when reading becomes a pleasure. School stops too early for this, and the literature provided to tempt the scholar onward is too limited. Beyond one or two little religious books, and the school reading books, we have nothing to feed the intelligence. This great poverty is accounted for by the fact that the Church has been progressing so rapidly in numbers, and the staff of Europeans is so limited, that no one has been able to set apart much time for literary work. Until we are able to set a linguist free from the continual claims of station work, we shall not be able to provide sufficient and suitable books for the thousands who profess ability to read.

Donald Fraser 